\title{
Assessing Financial Performance Based On Fundamental Factors From The Perspective Of The Signaling Hypothesis
}

\author{
Yuniningsih Yuniningsih ${ }^{1 *}$, Eko Purwanto ${ }^{2}$, Bowo Santoso ${ }^{3}$, Siti Aminah ${ }^{4}$, Egan Evanzha Yudha \\ Amriel $^{5}$ \\ yuniningsih@upnjatim.ac.id*,ekopasca@upnjatim.ac.id, manajemen.boow@gmail.com, \\ sitaminah1961@gmail.com, egan evanzha@yahoo.co.id
}

1.2.3.4.5. Faculty of Economic and Business, Universitas Pembangunan Nasional”Veteran” East Java, Indonesia

\begin{abstract}
Economic activity will be greatly influenced by how much funding sources are available financial institutions, especially from banks. This study aims to measure how much financial performance of Indonesian banks is influenced by financial fundamental factors. The analytical tool used to test hypotheses is using multiple linear regression. This research has fulfilled the normality test and classic assumptions which were carried out before the hypothesis test. The fundamental variable in this study uses financial performance as measured by Return On Investment (ROI) as the dependent variable. While the independent variables used are Net Interest Margin (NIM), Non Performing Loans (NPL), Loan to Deposit Ratio (LDR), and operational cost and income (CIO). The sample uses secondary data from 25 Indonesian banks listed on the Indonesia Stock Exchange in 2015-2018. The results showed that only the variable cost and operating income (CIO) had a significant influence on the company's financial performance. While the three other fundamental factors from NIM, LDR and NPL have no impact at all on financial performance. These results indicate the limitations of this study that the ratios used do not fully describe the dominant factors in evaluating financial performance.
\end{abstract}

Keywords: financial performance, fundamental factors, signaling hypothesis, funding, banking

\section{Introduction}

High economic activity is a major demand in maintaining and increasing economic growth. High economic growth requires a high investment as well. The realization of investment implementation is determined by a variety of factors, especially in terms of funding. Investment funding can come from own capital or foreign capital. Foreign capital can be obtained from both bank loans and by issuing bonds. This research emphasizes the role of banks as a source of funding both for the public and for companies. Emphasizing the role of banks because banks play a role in collecting and distributing funds. Whether or not the value of the bank will be determined by both non-fundamental and fundamental factors. Non-fundamental factors can originate from 
public trust and companies in saving and using funds in banks. Public trust in banks is determined by information received, specifically from financial performance. Many factors can be used as indicators in evaluating financial performance, which can signal good or bad performance. This research is based on signaling theory from [1] and was further developed by [2]. In accordance with the singnaling theory that was first developed by [1] in Job Signaling Market research, which involved two parties. Management as an internal party that signals through information, and investors as an external party that receives signals from the information provided. Then this theory was developed by [2] which explained that the executive had more information to give to the investor. The information can be in the form of financial statements or other things that reflect valuation. This information gives a positive or negative signal among investors towards the company's performance.

Financial performance analysis is used to determine the extent to which companies have used the rules of financial implementation properly and correctly [3][4]. [5] also stated that financial performance explained the good and bad condition of corporate or banking finances using financial analysis tools. Financial performance analysis in this study is used to see the level of profitability using the Return on Equity (ROE) ratio. ROE measures how much management efficiency in generating net income available to ordinary shareholders. Or in other words, to find out how much the rate of return on common stock equities. Return on equity is measured using the yield ratio of available profits, for shareholders with the total equity of ordinary shares.

Many factors affect financial performance or profitability. [6] examined the performance of profitability on fundamental factors, namely Non Performing Loans (NPL), Return on assets (ROA), Capital Adequacy Ratio (CAR) and Loan Loss Provision Ratio. He Maranata Pribadi (2017) bank profitability level with Non Performing Loans (NPL), Loan to Deposit Ratio (LDR), BOPO and Capital Adequacy Ratio factors. [7] [8] found financial performance with influencing factors, namely Debt, Company Size, and company growth. [9] research found company value in companies incorporated in the Jakarta Islamic Index with influencing factors namely Leverage, Investment and dividend with indicators of profitability, ownership, company size, growth, and liquidity. Research by [10] factors that influence company value are manager ownership and institutional ownership. In this study financial performance is measured using Net Interest Margin (NIM), Non Performing Loans (NPL), Loan to Deposit Ratio (LDR), and operational cost for income operational (COIO).

The first variable in this study is the Net Interest Margin (NIM). NIM is a market risk arising from the movement of market variables that will harm the bank. Net Interest Margin (NIM) is influenced by many factors, one of which is changes in interest rates and the quality of the bank's productive assets. Banks are required to be able to provide quality credit that can increase revenue. Along with the increase in income, finally the quality of productive assets will be maintained properly. The higher the NIM, the better the bank can increase interest income on the productive assets it manages. The higher interest income shows the better financial value of banks. The results of Muhamad ali's research, [11],[12] showed that NIM had an effect, especially in terms of profitability.

The second variable in this study is Non-performing Loans (NPL). NPL is a ratio used by banks to measure management's ability to resolve problem loans, [13]. Non-performing loans (NPL) are said to be a comparison between total non-performing loans and the total number of loans given to creditors. This is an indication that the higher or smaller the Non performing Loan (NPL) will give a negative or positive signal to the banking financial performance. If the higher NPL will give a negative signal to investors, this shows the company's financial performance is getting worse. Conversely the smaller the NPL will give a positive signal to investors, means the company has a better performance in resolving problem loans. The difference in research results 
between NPL and company performance is the basis of this study. Non-performing Loans (NPL) have a non-significant negative effect on Return On Assets, which is a proxy of company performance [14]; [15]. While the research of [6] showed NPL to have a significant negative effect with Return on Assets.

Another variable in this study is the Loan to Deposit Ratio (LDR). Loan to Deposit Ratio (LDR) according to Kasmir (2014) is the ratio between the amount of credit extended to debtors from creditors, and the total amount of funds owned by banks, both from public funds and from their own capital. In accordance with the signaling theory, the higher the LDR, the higher the bank's liquidity in distributing public funds. Conversely, the lower LDR ratio indicates the lower the liquidity of banks as creditors, in providing loans to debtors. It is associated with signaling theory that LDR has a significant negative effect on financial performance. The higher the Loan to Deposit Ratio (LDR), the higher the liquidity and the higher the financial performance of banks as creditors. There are several results of research that support and contradict the basic signaling theory. While LDR has no significant positive effect on Return On Assets, which is a ratio to measure financial performance is the result of research by [16]. While LDR has a significant positive effect on the ROA variable, which is the company's performance, is the result of research from [17], [15], [18]. In this variable it is hypothesized that the Loan to deposit ratio (LDR) has a positive effect on the financial performance of banks.

The fourth variable used to measure financial performance in this study is cost operational for operational income (COIO). Operational costs are costs associated with bank business activities, both interest costs, foreign exchange fees, labor costs and other costs, [19]. Operating income includes direct results from bank business activities such as interest, fees, commissions, foreign exchange income and other income. COIO is used as a bank measurement tool to reduce operational costs and increase operating income. The smaller the COIO ratio shows the more effective and efficient management of the company and ultimately gives a positive signal on financial performance and vice versa. It was concluded that operational cost for operational income (COIO) showed a negative influence on the financial performance of banks and vice versa. Some of the results of research that support the theory of signaling relating to the basic hypothesis between COIO and financial performance are [17], [15], [20].

The explanation above is used as a basis in this study on Conventional Commercial Banks listed on the Indonesia Stock Exchange (IDX) with financial statements for 2015 - 2018. The number of movements of financial performance of the 25 samples of conventional banks can be shown in figure 1.

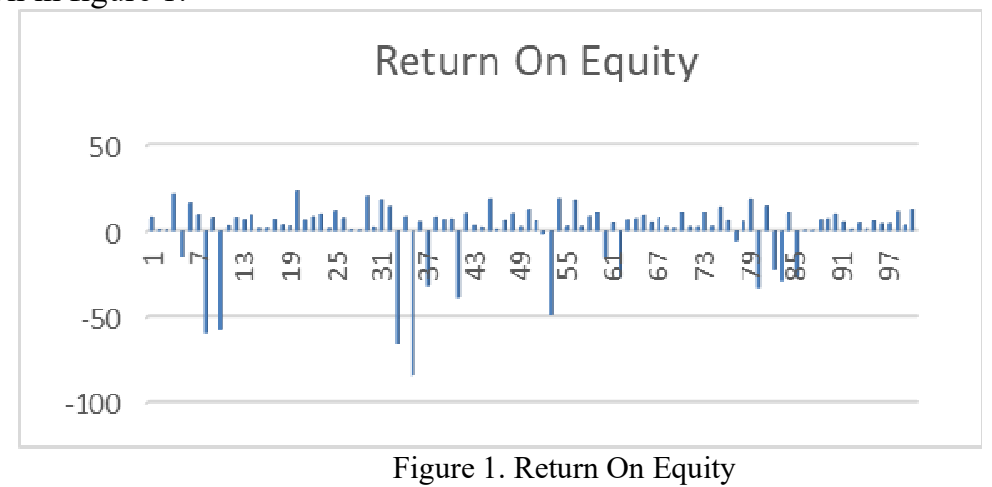

Figure 1 illustrates, there are times when banking financial performance shows poor and even higher value compared to financial performance that gives a positive value. Even the poor 
financial performance shows some values that are more than -50 and some even reach -83 . When the financial performance is stated to be good it shows the highest value of 23.41 and most of the values show 1 digit. This phenomenon is the basis for conducting research on how the fundamental factors in measuring the financial performance of Indonesian banks in the perspective of signaling theory.

Based on the explanation above, this study aims to measure the financial performance of banks as financial institutions with its fundamental factors seen from the perspective of the signaling hypothesis. The purpose of this study is broken down into 4 hypotheses..

H1. Net Interest Margin (NIM) has positive impact on the financial performance of banks

H2. Non-performing loans (NPL) have a negative impact on the financial performance of banks

H3. Loan to Deposit Ratio (LDR) have positive impact on the financial performance of banks

H4. cost operational for income operational (COIO) have negative impact on the financial performance of the Bank

\section{Research Method}

This study uses secondary data from Conventional Commercial Banks listed on the Indonesia Stock Exchange between 2015 and 2018, with a population of 36 banks. The research sample was taken using purposive sampling where 25 conventional banks were obtained. There are 11 Islamic banks that are not used because they do not fit the criteria used in this study. So the initial data from the sample of banks used 100 data obtained 25 banks X 4 years time period. After the data is collected, the next step is to do the outlier test. Outliner test is used to determine the presence or absence of extreme data with the aim that normality of data occurs. After the data normality occurs by conducting the normality test, the next step is to test the classical assumptions. The classic assumption test is performed to test the data to be free from multicollinearity, heteroscedasticity, and autocorrelation.

After testing the classical assumptions, hypothesis testing is performed using multiple linear regression. This study uses a dependent variable called financial performance that is measured using Return on equity (ROE). 4 independent variables consist of the ability to generate income as measured by Net Interest Margin (NIM_X1), measuring non-performing loans measured using Non-Performing loans (NPL_X2). The other 2 (two) independent variables are Loan to Deposit Ratio (LDR_X3) and operational cost for operational income (COIO_X4) LDR_X3 is used to measure how much liquidity the bank in lending is measured using. Whereas COIO_X4 is an independent variable that measures the efficiency of operational costs in generating revenue that is measured using.

\section{Result and Discussion}

\section{Result}

Before testing the hypothesis, normality of the data must be tested by testing the outline first. The normality test in this study uses the Kolmogorov-Smirnov One Sample Test. Outlier test is conducted to find out whether there is extreme data compared to other data. If there is extreme data, it must be eliminated. The data is normal if the results of the normality test show a significance of more than 0.05 . Normality test results of this study are presented in table 1 . 
Table 1 : Normality Test, One Sample Kolmogorov-Smirnov Test

\begin{tabular}{|c|c|c|c|c|}
\hline \multicolumn{2}{|l|}{ Information } & $\begin{array}{l}\text { Unstandardized } \\
\text { Residual } \\
\text { (I) }\end{array}$ & $\begin{array}{l}\text { Unstandardized } \\
\text { Residual } \\
\text { (II) }\end{array}$ & $\begin{array}{c}\text { Unstandardized } \\
\text { Residual } \\
\text { (III) }\end{array}$ \\
\hline \multicolumn{2}{|c|}{$\mathrm{N}$} & 100 & 84 & 84 \\
\hline \multirow[t]{2}{*}{ Normal Parameters ${ }^{\text {a.b }}$} & Mean & .0000000 & .0000000 & .0000000 \\
\hline & Std. Deviation & 7.39618332 & .61757135 & .21308289 \\
\hline Most Extreme & Absolute & .143 & .099 & .063 \\
\hline \multirow{2}{*}{ Differences } & Positive & .132 & .099 & .063 \\
\hline & Negative & -.143 & -.058 & -.057 \\
\hline \multicolumn{2}{|l|}{ Test Statistic } & .143 & .099 & .063 \\
\hline \multicolumn{2}{|l|}{ Asymp. Sig. (2-tailed) } & $.000^{\mathrm{c}}$ & $.042^{\mathrm{c}}$ & $.200^{\mathrm{c}, \mathrm{d}}$ \\
\hline
\end{tabular}

Source: processed data

Table 1 shows the 3 normality test results using the One Sample Kolmogorov-Smirnov Test. Before the normality test is done, an outlier test with 100 data is performed. The first outlier test occurs outlier data and automatically when the normality test occurs data abnormalities. The data abnormalities in the first test show a significance value of 0,000 and this result is smaller than the level of significance of 5\%. After that the data is eliminated from the first outlier test of 16 data. Then the remaining 84 data were transformed and then tested outliers again and no data experienced outliers. But after being tested for normality the results show abnormalities of the data because the significance value of 0.042 is still smaller than 0.05 . The third step is to transform data again from 84 data and re-test normality. The third normality test with 84 new data produces normal data because the test results show a significance value of 0.200 , greater than the level of significance of 0.05 . After normal data, the next step is to test the classical assumptions in the form of multicollinearity, heteroscedasticity, and autocorrelation tests. The results of the classic assumption test and R Square are presented in table 2.

Table 2. Multicollinearity, Heteroskedastisitas, Autocorrelation And R Square

\begin{tabular}{|c|c|c|c|c|}
\hline Model & $\begin{array}{l}\text { Multicollinerity } \\
\text { VIF }\end{array}$ & $\begin{array}{l}\text { Heteroscedasticity } \\
\text { Significance }\end{array}$ & $\begin{array}{l}\text { Autocorellation } \\
\text { Durbin-Watson }\end{array}$ & R Square \\
\hline (Constant) & - & 0.012 & 1.890 & .238 \\
\hline NIM_X1 & 1.404 & 0.949 & & \\
\hline NPL_X2 & 1.516 & 0.704 & & \\
\hline LDR_X3 & 1.363 & 0.298 & & \\
\hline COIO__X4 & 1.418 & 0.053 & & \\
\hline
\end{tabular}

Based on table 2, the Multicollinerity test is used to determine whether there is a correlation between the independent variables. Research is considered good if there is no Multicollinerity, if the value of the Variance Inflanation factor (VIF) of the independent variable is less than 10 (VIF <10). The results of the study of 4 independent variables from NIM X1, NPL_X2, LDR_X3 and COIO_X4 VIF values are still less than 10. The conclusion that this study did not occur Multicollinerity. 
Table 2 also shows the results of the Heteroscedasticity used to determine whether the regression model of this study shows that there is a similarity in residual variance between one observation to another. This research uses glacier test. The study stated no Heteroscedasticity, if the significance value is greater than 0.05 . based on table 2 shows that the Heteroscedasticity value of all independent variables, namely NIM_X1, NPL_X2, LDR_X3 and COIO_X4 values more than 0.05 which means there is no heteroscedasticity.

Table 2 also displays another classic assumption, Autocorellation. Autocorellation test is used to find out whether multiple linear regression model there is a correlation between residuals between one observation to another or previous observations. The autocorellation in this study uses the Durbin Watson test which shows a value of 1,890 . while the table value at the 0.05 significance level shows dl of 1.5472 while du of 1.7462. if the Autocorellation value is between $\mathrm{dl}<\mathrm{d}<4-\mathrm{du}$, then there is no Autocorellation. Based on the results of the Watson durbin table 2, the Autocorellation is $1.5472<1.890<4-1.7462$ or $1.5472<1.890<2.2538$, so it can be concluded that this study is free from Autocorellation.

From the results of the classic assumptions test previously explained, this study fulfills the classical assumptions because it is free of multicollinearity, heteroscedasticity, and autocorrelation. Even though the classical assumptions are met, the independent variable used in the study shown by $\mathrm{R}$ Square is less than $50 \%$. Where $\mathrm{R}$ Square is only able to explain the financial performance of $23.8 \%$. Other financial performance of $76.2 \%$ is explained by other variables outside the independent variables used in this study.

After testing the classical assumptions, a hypothesis test is performed using multiple linear regression. Test this hypothesis to find out how large the independent variables in this study can measure and affect financial performance. The level of significance of this study uses $10 \%$. The results of the hypothesis test of this study are presented in table 3.

Tabel.3 . Result of hypothesis test Multiple Linear Regression

\begin{tabular}{|c|c|c|c|}
\hline Model & $\mathrm{t}$ & & Significance \\
\hline Constant & 6.086 & & .000 \\
\hline NIM_X1 & -.582 & .562 & \\
\hline NPL_X2 & 1.800 & & .076 \\
\hline LDR_X3 & -.113 & .910 & \\
\hline COIO_X4 & -8.717 & & .000 \\
\hline
\end{tabular}

Based on table 3 , the level of significance of $10 \%$ shows only two variables that can affect financial performance, namely NPL_X2 and COIO_X4. The test results of the NPL_X2 variable showed a significance of 0.076 in a positive direction, although it influenced financial performance but the direction was not in accordance with the hypotheses. COIO_X4 variable significance test results of 0.000 with a negative direction and in accordance with what was hypothesized. While the 2 variables NIM_X1 and LDR_X3 significance test results show results 
that do not affect financial performance because the significance value is more than $10 \%$. NIM_X1 test results show a significance of 0.562 greater than the level of significance of $10 \%$ with a negative direction. so NIM_X1 doesn't match what was hypothesized. The same thing is shown by the LDR_X3 test results where the significance is 0.910 with a negative direction. LDR_X3 does not support the hypothesis.

\section{Discussion}

Net interest margin (NIM) in this study does not affect the financial performance of banks, This shows the NIM is not in accordance with what was hypothesized. This study hypothesizes that net interest margin has a positive effect on financial performance. Banks will have a high Net interest margin (NIM) if the bank is able to channel funds owned by providing quality credit. This shows if the bank must be able to assess which prospective debtor meets the $5 \mathrm{C}$, namely charter, capacity, capital, collateral and condition. Besides the assessment using 5C. Banks also need to dig deeper information about potential creditors. This information can be obtained internally or externally. If this is done well, the bank will get a good quality debtor. Quality debtors are debtors who are able to pay obligations on time, and the funds received are used for productive matters. A good debtor causes banks to increase revenue while increasing the financial performance of banks. Conversely, if the debtor is not qualified, it will reduce income due to the number of bad loans, which will reduce the financial performance of banks. But the results of the study showed insignificant results. High or low margins, will not affect the high or low financial performance. This is made possible by the high or low margins obtained, largely due to how much the banks can respond to market risk turmoil. Moreover, the financial performance of banks is much influenced by other variables besides Net Interest Margin. As well as other variables outside the variables used in this study and another possibility is a financial analysis tool in measuring margins using different ratios other than Net Interest Margin (NIM). The cause of the insignificance of the possibility of banking revenue is also obtained apart from the core business that is obtained outside the core business of banking.

Non Performing Loans (NPLs) are hypothesized to have a negative impact on financial performance. Non-Performing Loans (NPLs) are financial analysis tools, which are used to measure how much non-performing loans the company is bearing from loans. The results showed a positive influence and not in accordance with the hypothesized and signaling theory. These results indicate that the greater the non-performing loans the banking sector will bear, the greater the financial performance of the banking system. The possibility of bad loans faced by banks is credit that is channeled to debtors, especially companies that are still in the initial investment phase and which have not been fully operational. So the payment of debt and interest in full and routine has not been fully done because the funds are still used to finance the operations of the business. Full repayment of loans and interest must wait for company profits. This result also shows that banking funds have been absorbed by many users, both for consumption and for production. The greater the funds absorbed into the community, the greater the risk borne. Risk because it is not in accordance with the time of payment, especially for debtors who just started a business. Conversely, the smaller the bad credit, the greater the financial performance. This shows the possibility of banks not distributing existing funds, resulting in as if there were no problem loans. These results are not in accordance with the study of [16] and [6] Gizaw et al (2015) where the results of NPL have a negative significant effect on Return on assets.

The hypothesis in the loan to deposit ratio (LDR) has a positive effect on financial performance. While the results of the study show that Loan to Deposit Ratio (LDR) is negative, and has no effect on the financial performance of banks. This result does not support hypothesis 
and signaling theory. This shows that the amount of credit extended to debtors does not affect the financial performance of banks. A lot of funds are channeled to users but low returns resulting in smaller revenues. If related to Non Performing Loans (NPL), they are interrelated. Or this shows the likelihood that the funds available are largely channeled to the community only for consumption use. As a result, the amount of funds distributed is not too large, if compared to the funds channeled to investors whose purpose is for production or business. The impact of the debtor's inaccurate target bank earnings will not have a major impact on financial performance. It can be concluded that this study shows that there is no balance between lending and the amount of funds available. These results are not in accordance with the research of [17], [15], [18].

This study hypothesizes that operational costs for operational income (COIO) have a negative effect on bank financial performance. The results of this study support this hypothesis. This research shows that banks can perform efficiency efficiency, especially in terms of operational costs. Operational activities carried out by banks are in accordance with work programs and meet targets so that efficiency levels occur. Work efficiency will affect the efficiency of operational costs or banking activities. The costs of banking activities can be related to interest costs, foreign exchange fees, labor costs and other costs related to daily banking activities. The results of this study are in accordance with the signaling theory, where the more efficient in conducting banking activities, the more efficient in operational financing is issued and will result in better financial performance. This shows that if banking operations are carried out correctly and on target, they will save operational costs and increase revenues. Increasing bank income will also have an impact on employee welfare while increasing the amount of funds available to credit users. Conversely the more inefficient or greater operational financing, it will not improve the banking financial performance. The results of this study are also in accordance with the research of [17], [15], [20].

\section{Acknowledgement}

I would like to thank this research to my institute UPN "Veteran" east Java, Indonesia for providing the opportunity to conduct research. Moreover, the UPN "Veteran" East Java has also provided enormous opportunities in motivating and appreciating each lecturer's performance.

\section{References}

[1] M. Spence, 'Competitive and optimal responses to signals: An analysis of efficiency and distribution', J. Econ. Theory, vol. 7, no. 3, pp. 296-332, 1974.

[2] S. A. Ross, 'The determination of financial structure: the incentive-signalling approach', bell J. Econ., pp. 23-40, 1977.

[3] B. Kasmir and L. K. Lainnya, 'Jakarta: PT', RajaGrafindo Persada, 2010.

[4] Y. Yuniningsih, M. Taufiq, E. Wuryani, and R. Hidayat, 'Two stage least square method for prediction financial investment and dividend', in Journal of Physics: Conference Series, 2019, vol. 1175, no. 1, p. 12212.

[5] I. Fahmi, 'Analisis laporan keuangan'. Bandung: Alfabeta, 2011.

[6] M. Gizaw, M. Kebede, and S. Selvaraj, 'The impact of credit risk on profitability performance of commercial banks in Ethiopia', African J. Bus. Manag., vol. 9, no. 2, pp. 59-66, 2015. 
[7] Y. Yuniningsih, N. A. Hasna, M. B. N. Wajdi, and S. Widodo, 'Financial Performance Measurement Of With Signaling Theory Review On Automotive Companies Listed In Indonesia Stock Exchange', IJEBD (International J. Entrep. Bus. Dev., vol. 1, no. 2, pp. 167-177, 2018.

[8] Y. Yuniningsih, V. N. S. Lestari, N. Nurmawati, and B. N. Wajdi, 'Measuring Automotive Company's Capabilities in Indonesia in Producing Profits Regarding Working Capital', J. Terap. Manaj. dan Bisnis, vol. 4, no. 1, pp. 67-78, 2018.

[9] Y. Yuniningsih, T. Pertiwi, and E. Purwanto, 'Fundamental factor of financial management in determining company values', Manag. Sci. Lett., vol. 9, no. 2, pp. 205-216, 2019.

[10] Y. Yuniningsih, 'Seberapa Besar Kepemilikan Saham Berperan Dalam Penentuan Nilai Perusahaan Dengan Tinjauan Agency Theory', J. Darussalam J. Pendidikan, Komun. dan Pemikir. Huk. Islam, vol. 9, no. 1, pp. 107-115, 2017.

[11] M. Ali, 'Pengaruh Net Interest Margin (NIM), Biaya Operasional Terhadap Pendapatan Operasional (BOPO), Loan to Deposit Ratio (LDR) Dan Non Performing Loan (NPL) Terhadap Return On Assets (ROA)', J. Ris. Akunt. dan Keuang., vol. 5, no. 2, pp. 1377-1392, 2017.

[12] W. F. Pinasti and R. R. I. Mustikawati, 'Pengaruh CAR, BOPO, NPL, NIM Dan LDR Terhadap Profitabilitas Bank Umum Periode 2011-2015', Nominal, Barom. Ris. Akunt. dan Manaj., vol. 7, no. 1, 2018.

[13] L. Dendawijaya, 'Banking management', Bogor Ghalia Indones., 2009.

[14] A. Widianata, 'Analisis pengaruh rasio CAR, NPL, NIM, BOPO, LDR terhadap ROA', Skripsi dipublikasikan, 2012.

[15] B. Ponco, 'Analisis Pengaruh CAR, NPL, BOPO, NIM dan LDR terhadap ROA', Univ. Diponegoro, 2008.

[16] M. I. U. P. Warsa and I. K. Mustanda, 'Pengaruh CAR, LDR dan NPL Terhadap ROA Pada Sektor Perbankan di Bursa Efek Indonesia', E-Jurnal Manaj., vol. 5, no. 5, 2016.

[17] A. B. Nusantara, 'Analisis pengaruh NPL, CAR, LDR, dan BOPO terhadap profitabilitas bank (perbandingan bank umum go publik dan bank umum non go publik di Indonesia periode tahun 20052007)'. program Pascasarjana Universitas Diponegoro, 2009.

[18] R. Kurniawati, S. Alam, and M. Nohong, 'PENGARUH KEPEMILIKAN INSTRITUSIONAL, CAPITAL ADEQUACY RATIO,(CAR), LOAN DEPOSIT RATIO (LDR) TERHADAP PROFITABILITAS PADA BEBERAPA BANK YANG TERCATAT DI BURSA EFEK INDONESIA', Hasanuddin J. Appl. Bus. Entrep., vol. 2, no. 1, pp. 83-94, 2019.

[19] L. Dendawijaya, 'Manajemen Perbankan Edisi Revisi', Ciawi Bogor, Ghalia Indones., 2009.

[20] P. Mahardia, 'Analisis pengaruh rasio CAR, BOPO, NPL, NIM dan LDR terhadap kinerja keuangan perbankan (studi kasus perusahaan perbankan yang tercatat di bej periode juni 2002 â juni 2007)'. Program Pascasarjana Universitas Diponegoro, 2008. 